\title{
PENGARUH BUDAYA ORGANISASI, KEPEMIMPINAN, DAN MOTIVASI KERJA TERHADAP KEPUASAN KERJA KARYAWAN CV SURYA RAYA
}

\author{
Laksmi Sito Dwi Irvianti; Rido Justisia Prabowo; \\ Gugi Abdel Permana ${ }^{3}$
}

Jurusan Manajemen, Fakultas Ekonomi dan Komunikasi, BINUS University Jln. K.H. Syahdan No. 9, Palmerah, Jakarta Barat 11480

laksmisito@yahoo.com

\begin{abstract}
This research was conducted on CV Surya Raya which is engaged in car shipping. The aim of this study is to determine the influence of organization culture, leadership, and working motivation partially to employees' satisfaction in CV Surya Raya. The data was collected by conducting interviews with the company and distributing questionnaires to 67 employees as respondents and then analyzed using linear regression analysis method. From the research results, leadership variable does not have a significant impact on employees' job satisfaction in CV Surya Raya. Whereas, the motivation variable has greater influence on job satisfaction of CV Surya Raya employees compared to the organization's culture.
\end{abstract}

Keywords: organization culture, leadership, working motivation, working satisfaction

\begin{abstract}
ABSTRAK
Penelitian ini dilakukan CV Surya Raya yang bergerak dalam bidang pengiriman mobil ke berbagai daerah di Indonesia. Tujuan penelitian ini adalah untuk mengetahui pengaruh budaya organisasi, kepemimpinan, dan motivasi kerja secara parsial terhadap kepuasan kerja karyawan di CV Surya Raya.Pengumpulan data dilakukan dengan cara melakukan wawancara kepada pihak perusahaan dan menyebarkan kuesioner terhadap 67 orang karyawan sebagai responden dan kemudian dianalisis dengan mengunakan metode analisis regresi linear. Dari penelitian ini diperoleh hasil bahwa variabel kepemimpinan tidak memiliki pengaruh yang signifikan terhadap kepuasan kerja karyawan CV Surya Raya. Sedangkan variabel motivasi kerja memilki pengaruh yang lebih besar terhadap kepuasan kerja karyawan CV Surya Raya dibandingkan dengan budaya organisasi.
\end{abstract}

Kata kunci: budaya organisasi, kepemimpinan, motivasi kerja, kepuasan kerja 


\section{PENDAHULUAN}

Manusia memegang peranan yang penting dalam semua proses kehidupan, karena manusia sangat pemikir, perencana, sekaligus pelaksana segala kegiatan. Oleh karena itu manusia merupakan salah satu sumber daya, yaitu sumber daya manusia, sumber daya alam, dan sumber daya capital. Untuk mencapai tujuan yang diinginkan, perusahaan perlu melakukan manajemen sumber daya yang baik. Manajemen sumber daya manusia perlu dilakukan agar sumber daya manusia potensial yang dimiliki perusahaan dapat diarahkan secara efektif dan efisien.

CV Surya Raya adalah salah satu perusahaan yang ada khususnya di Jakarta. Sejak didirikan pada tahun 1998, CV Surya Raya memiliki relasi yang terus bertambah dari masa ke masa dan juga sudah menjangkau keseluruh wilayah indonesia. Menurut pemilik perusahaan ini, keberhasilan utama dalam menjalankan usaha merupakan hasil kerjasama di antara para karyawan yang bekerja dengan baik untuk melayani pelanggan atau pengguna jasa pengiriman mobil. Keberhasilan CV Surya Raya, dalam memuaskan konsumen yang memakai jasa ini, tidak lepas dari dukungan manajemen serta karyawan yang merupakan aset bagi perusahaan.

Budaya organisasi memiliki dampak pada efisiensi dan efektivitas organisasi. Oleh karena itu, budaya organisasi merupakan bagian penting dalam memahami organisasi seluruhnya. Budaya organisasi dibangun dari kepercayaan yang dipegang teguh secara mendalam tentang bagaimana organisasi seharusnya dijalankan (Munandar, 2001). Budaya merupakan sistem nilai organisasi dan akan mempengaruhi cara pekerjaan dilakukan dan cara pegawaiberperilaku. Individu dapat mampu dan efisien tanpa tergantung pada orang lain, tetapi perilakunya tidak sesuai dengan budaya organisasi, maka orang tersebut tidakakan berhasil dalam organisasi. Budaya organisasi atau budaya perusahaan sangat penting peranannya dalam mendukung terciptanya suatu organisasi yang efektif.

Budaya di CV Surya Raya ini, terbina sangat kuat. Menurut pemiliknya, visi dan misi juga peraturan-peraturan yang ditetapkan sejak perusahaan ini berdiri sampai sekarang, tidak mengalami banyak perubahan. Penerapannya selalu berhasil dengan baik dari tahun ke tahun, walaupun adanya pergantian karyawan, sehingga budaya perusahaan ini diyakini usaha pemiliknya sangat membantu dalam menetapkan standar kualitas sumber daya manusia yang dimiliki perusahaan ini.

Salah satu aspek penting yang mencerminkan kualitas sumber daya manusia adalah perilaku baik dari atasan ataupun bawahan di dalam jenjang suatu organisasi. Di satu sisi biasanya pola perilaku seorang bawahan akan banyak diwarnai oleh perilaku atasannya sebagai pemimpin oleh karena kepemimpinannya sehari-hari. Kepemimpinan merupakan proses anggaran dan mempengaruhi aktivitas yang berkaitan dengan tugas dari para anggota kelompok. Kepemimpinan yang efektif tergantung dari landasan manajerial yang kokoh.

Sebagai suatu perusahaan yang telah lama berjalan ada beberapa kendala yang timbul di dalam usaha ini. Contohnya, para karyawan yang sebagian besar adalah driver (supir), yang menjadi tombak perusahaan ekspedisi ini adalah tingkat komplain dari konsumen, yang tertuju kepada CV Surya Raya. Berikut ini adalah dua garis besar penyebab terjadinya komplain konsumen terhadap CV Surya Raya ialah keterlambatan pengiriman yang disebabkan oleh kondisi cuaca dan kurangnya ketelitian terhadap mobil yang dikirim sehingga ditemukannya kecacatan di mobil yang dikirim tersebut. Penyebabpenyebab tersebut mempengaruhi sikap pemilik CV Surya Raya terhadap driver yang melakukan keterlambatan atau ketidak hati-hatiannya terhadap mobil yang dikirimnya. Teguran akan di berikan kepada driver yang melakukan kesalahan. Sanksi yang biasanya di berikan oleh perusahaan terhadap pekerjanya yang melakukan kesalahan adalah seperti pemotongan komisi atau suspend shift pengiriman mobil. Hal ini mempengaruhi kepuasan kerja karyawan dan kinerja dari driver tersebut. Menurut wawancara dari pemilik CV Surya Raya perihal penurunan kinerja karyawan karena teguran 
dan sanksi yang diberikan adalah seperti keterlambatan masuk kerja, waktu pengiriman mobil yang tidak tepat waktu, kecacatan mobil yang dikirim, dan ketidak hati-hatian dalam proses pengiriman mobil.

Lima landasan kepemimpinan yang kokoh adalah: cara berkomunikasi, pemberian motivasi, kemampuan memimpin, pengambilan keputusan, dan kekuasaan yang kokoh. Seorang pemimpin yang cenderung berperilaku instruktif atau otokratif dapat mempersulit seorang bawahan yang memiliki kemauan atau kemampuan untuk berkembang lebih lanjut. Sebaliknya seorang pemimpin yang delegatif akan membingungkan karyawan yang kurang memiliki motivasi dan atau bagi karyawan yang tidak memiliki kemampuan untuk berkembang. Menurut pemilik CV Surya Raya, pemimpin yang baik adalah pemimpin yang bisa memberikan kepuasan kerja dengan memotivasi kerja karyawannya. Motivasi kerja merupakan dorongan yang timbul dari dalam diri pegawai dimana di dalamnya terdapat unsur-unsur motivasi yang berwujud pada tingkat upah, keselamatan dan keamanan kerja, kebutuhan sosial, lingkungan kerja, penghargaan dan aktualisasi diri itu diharapkan akan mendorong tenaga kerja untuk lebih berkualitas dalam berkarya. Salah satu unsur eksternal yang mendorong timbulnya motivasi kerja adalah budaya organisasi dan iklim kerja yang terbentuk di sekitar tempat karyawan bekerja (Umar, 2001).

Brahmasari \& Suprayetno (2008) menyatakan menciptakan kepuasan kerja karyawan adalah tidak mudah karena kepuasan kerja dapat tercipta jika variabel-variabel yang mempengaruhinya antara lain motivasi kerja, kepemimpinan dan budaya organisasi/perusahaan dapat diakomodasikan dengan baik dan diterima oleh semua karyawan di dalam suatu organisasi /perusahaan.

Menurut pemilik CV Surya Raya, para karyawan punya berbagai motivasi, karena para karyawan berasal dari berbagai macam latar belakang. Sehingga dariberbagai macam motivasi tersebut timbul berbagai tingkah laku. Hal ini tentu saja berpengaruh terhadap kualitas sumber daya manusia di perusahaan ini, Sebagai perusahaan perorangan, manajemen secara keseluruhan dipegang oleh pemilik perusahaan, berusaha untuk menciptakan suasana kekeluargaan dalam berinteraksi dengan karyawan. Karyawan diajak untuk merasa memiliki dan bertanggung jawab terhadap keberhasilan perusahaan dalam menghadapi persaingan. Bila karyawan bisa mempunyai rasa memiliki terhadap perusahan, artinya pemilik berhasil memuaskan karyawannya. Kepuasan kerja para karyawan selain didukung oleh budaya kerja yang kuat, peran pemilik juga tidak kalah besarnya. Pimpinan perusahaan yang sekaligus juga merupakan pemilik dari CV Surya Raya, selalu berusaha menciptakan komunikasi yang baik dengan para bawahan dengan terjun bergabung dengan karyawan melakukan tugas sehari-hari, sekaligus memberikan motivasi agar karyawan mau bekerja dengan giat, sehingga para karyawan merasakan kepuasan selama bekerja di CV Surya Raya.

\section{Identifikasi Masalah}

Setelah mengulas sedikit permasalahan yang akan diteliti pada latar belakang di atas, maka permasalahan yang dapat dirumuskan antara lain adalah: (1) bagaimana pengaruh budaya organisasi terhadap kepuasan kerja karyawan CV Surya Raya; (2) bagaimana pengaruh kepemimpinan terhadap kepuasan kerja karyawan CV Surya Raya; dan (3) bagaimana pengaruh motivasi kerja terhadap kepuasan kerja karyawan CV Surya Raya.

\section{Pengertian Budaya Organisasi}

Menurut Wood, Wallace, Zeffane, Schermerhorn, Hunt, Osborn (2001), budaya organisasi adalah sistem yang dipercayai dan nilai yang dikembangkan oleh organisasi dimana hal itu menuntun perilaku dari anggota organisasi itu sendiri. Sedangkan menurut Tosi, Rizzo, Carroll seperti yang dikutip oleh Munandar (2001), budaya organisasi adalah cara-cara berpikir, berperasaan dan bereaksi berdasarkan pola-pola tertentu yang ada dalam organisasi atau yang ada pada bagian-bagian organisasi. 
Cushway dan Lodge (2000) berpendapat bahwa budaya organisasi merupakan sistem nilai organisasi dan akan mempengaruhi cara pekerjaan dilakukan dan cara para karyawan berperilaku. Robbins dan Coulter (2004) mendefisinikan budaya organisasi sebagai "suatu sistem makna bersama yang dianut oleh anggota organisasi yang menentukan, sebagaian besar cara mereka bertindak" (hal. 58). Dapat disimpulkan bahwa yang dimaksud dengan budaya organisasi dalam penelitian ini adalah sistem nilai organisasi yang dianut oleh anggota organisasi, yang kemudian mempengaruhi cara bekerja dan berperilaku dari para anggota organisasi.

\section{Fungsi Budaya Organisasi}

Rivai menjabarkan beberapa fungsi organisasi (2008), budaya organisasi melakukan sejumlah fungsi di dalam sebuah organisasi, yaitu: (1) budaya mempunyai suatu peran menetapkan tapal batas, artinya budaya menciptakan perbedaan yang jelas antara suatu organisasi denagn organisasi yang lain; (2) budaya memberikan identitas bagi para anggota organisasi; (3) budaya mempermudah timbulnya komitmen yang lebih luas dan pada kepentingan individu; (4) budaya itu menigkatkan kemantapan sistem sosial; (5) budaya sebagai mekanisme pembuat makna dan kendali yang memandu serta membentuk sikap dan perilaku karyawan.

\section{Definisi Kepemimpinan}

Kepemimpinan adalah proses untuk mempengaruhi kebiasaan orang lain demi pencapaian bersama menurut Madura (2001) Kepemimpinan adalah kemampuan meyakinkan dan menggerakan orang lain agar mau bekerja sama di bawah kepemimpinannya sebagai suatu tim untuk mencapai suatu tujuan tertentu (Samsudin 2006), sehingga dapat di nyatakan bahwa kepemimpinan merupakan proses mempengaruhi atau menggerakan bawahan agar mau melaksanakan apa yang diinginkan atau diharapkan oleh pimpinan tersebut. Menurut pendapat para ahli di atas dapat di simpulkan bahwa kepemimpinan adalah proses mempengaruhi dan menggerakan bawahan untuk mencapai tujuan bersama yang di inginkan.

\section{Indikator Kepemimpinan}

Berdasarkan kajian teori tentang kepemimpinan, maka untuk mengetahui suatu kepemimpinan dalam organisasi dapat dilihat dari fungsi kepemimpinan sebagai fasilitator, penaksir, peramal, penasehat, dan pemampu. Sebagai fasilitator, pimpinan membantu mengenal karir, membantu mengenal pekerjaaan yang dapat dipasarkan, menunjukkan pentingnya perencanaan jangka panjang, menciptakan suasana terbuka dan penerimaan, membantu memahami keinginan pegawai. Sebagai penaksir pimpinan memberikan umpan balik kepada pegawai, memastikan pegawai memahami standar kerja, mendengarkan usulan dan keluhan pegawai, menjelaskan hubungan kinerja dengan karir pegawai, memberi saran terhadap pelaksanaan kerja secara rinci. Sebagai peramal pimpinan memberi informasi tentang organisasi, profesi dan lingkup organisasi, membantu memperoleh sumber informasi, menunjukkan realitas kultur dan politik organisasi, menjelaskan arah strategik organisasi kepada tim. Sebagai penasehat, pimpinan membantu mengidentifikasi karir, membantu memilih karir yang realistis, menghubungkan tujuan karir dengan syarat dan arah strategik organisasi, menunjukkan sumber dukungan dan halangan dalam meniti karir. Sebagai pemampu, pimpinan membantu secara individual untuk membuat rencana kerja secara detail dan menghubungkan pegawai dengan sumbersumber yang diperlukan dalam melaksanakan rencana kerja.

\section{Definisi Motivasi Kerja}

Menurut Kreitner dan Kinicki (2008) motivasi adalah kumpulan proses psikologis yang menyebabkan pergerakan, arahan, dan kegigihan dari sikap sukarela yang mengarah pada tujuan. Menurut Colquitt, LePine, dan Wesson (2009) motivasi suatu kumpulan kekuatan yang energik yang 
mengkoordinasi di dalam dan di luar diri seorang pekerja, yang mendorong usaha kerja, dalam menentukan arah, intensitas, dan kegigihan.

Menurut George dan Jones (2005) motivasi kerja adalah suatu kekuatan psikologis di dalam diri seseorang yang menentukan arah perilaku seseorang di dalam organisasi, tingkat usaha, dan kegigihan di dalam menghadapi rintangan. Dari beberapa pendapat di atas, motivasi kerja bisa di simpulkan sikap psikologis yang menyebabkan pergerakan, arahan, dan kegigihan seorang yang mendorong usaha kerja, dalam menentukan arah, intensitas, dan kegigihan yang berpengaruh kepada organisasi di mana ia bekerja.

\section{Dasar-dasar Pokok Motivasi}

Beberapa teori motivasi yang dikenal, menurut Rivai dan Sagala (2009), yaitu: teori kebutuhan (hierarchical of needs theory), teori motivasi yang sangat terkenal adalah teori kebutuhan yang dikemukakan oleh Abraham Maslow. Menurut Maslow bahwa pada setiap diri manusia itu terdiri dari atas lima kebutuhan yaitu; kebutuhan secara fisiologis, rasa aman, sosial, penghargaan, dan aktualisasi diri.

Selain itu, McClelland theory of needs, David McCelland menganalisis tentang tiga kebutuhan manusia yang sangat penting di dalam organisasi atau perusahaan tentang motivasi mereka. McClelland theory of needs memfokuskan kepada tiga hal yaitu: (1) kebutuhan dalam mencapai kesuksesaan (need for achievement), kemampuan untuk mencapai hubungan kepada standar perusahaan yang telah ditentukan juga perjuangan karyawan untuk menuju keberhasilan, kebutuhan dalam kekuasaan atau otoritas kerja (Need for power); (2) kebutuhan untuk membuat orang berperilaku dalam keadaan yang wajar dan bijaksana di dalam tugasnya masing-masing; (3) kebutuhan untuk berafiliasi (needs for affiliation), hasrat untuk bersahabat dan mengenal lebih dekat rekan kerja atau para karyawan di dalam organisasi.

Need for achievement. Beberapa orang memiliki keinginan untuk mencapai kesuksesan. Mereka berjuang untuk memenuhi ambisi secara pribadi daripada mencapai kesuksesan dalam bentuk penghargaan perusahaan atau organisasi. Sehingga mereka melakukannya selalu lebih baik dan lebih efisien dari waktu ke waktu. Maksud high achiever di sini adalah seseorang atau karyawan yang dalam menyelesaikan tugasnya selalu lebih baik dari yang lain (better than others).

Mereka ini (high achiever) selalu mencari suasana kerja dalam suatu proyek atau keadaan di mana mereka dapat memikul tanggung jawab secara pribadi untuk memecahkan masalahnya dan memperoleh kembali jawaban yang cepat dari suasana tersebut. Jadi, dapat mereka katakan mudah untuk mengetahui sulit atau tidaknya, bahkan dapat meningkatkannya atau tidak dalam suatu pekerjaan. Mereka tidak berpikir untung-untungan tetapi dengan perhitungan yang akurat dan tepat. Mereka merencanakan dengan matang segala sesuatunya, mereka bukanlah meraih kesempatan dalam kesempitan untuk meraih kesuksesan. Mereka ini berkinerja bagus dan baik ketika mereka menerima tanggung jawab dengan kemungkinan 50- 50 atau seimbang. Mereka akan menghadapinya dengan penuh tanggung jawab baik dalam kegagalan atau kesuksesan dalam menyelesaikan tugasnya atau pekerjaannya.

Need for Power. Beberapa orang mungkin selalu untuk memiliki pengaruh, dihormati dan senang mengatur sebagian manusia lainnya. Manusia semacam ini justru senang, dengan tugas yang dibebankan kepadanya atau statusnya dan cenderung untuk lebih peduli dengan kebanggaan, prestise, dan memperoleh pengaruh terhadap manusia lainnya. Need for affiliation. Kebutuhan ini menempati posisi paling akhir dari riset para pakar manajemen. Maksudnya di sini, orang yang memiliki kebutuhan seperti ini tentu mereka memiliki motivasi untuk persahabatan, menanggung dan bekerja sama daripada sebagai ajang kompetisi di dalam suatu organisasi. Termasuk di dalam hal pengertian satu dengan lainnya. 


\section{Teori ERG}

Teori ERG menyebutkan ada tiga kategori kebutuhan individu, yaitu eksistensi (existence), keterhubungan (relatedness) dan pertumbuhan (growth), karena itu disebut sebagai teori ERG, yang berupa: (1) kebutuhan eksistensi untuk bertahan hidup, kebutuhan fisik; (2) kebutuhan keterhubungan adalah kebutuhan untuk berhubungan dengan orang lain yang bermanfaat seperti keluarga, sahabat, atasan, keanggotaan di dalam masyarakat; dan (3) kebutuhan pertumbuhan adalah kebutuhan untuk menjadi produktif dan kreatif, misalnya diberdayakan di dalam potensi tertentu dan berkembang secara terus-menerus.

\section{Definisi Kepuasan Kerja}

Kepuasan kerja adalah sikap umum terhadap pekerjaan seseorang, yang menunjukan perbedaan antara jumlah penghargaan yang di terima pekerja dan jumlah yang mereka yakini seharusnya mereka terima (Robbins, dalam Wibowo, 2007). Menurut George dan Jones (2005), merupakan kumpulan perasaan dan kepercayaan yang dimiliki seseorang tentang pekerjaan mereka. Menurut Kreitner dan Kinicki, (2008), suatu respon yang mempengaruhi atau emosional terhadap berbagai segi dari pekerjaan seseorang. Dari pendapat beberapa ahli tersebut bisa disimpulkan kepuasan kerja adalah sikap umum terhadap pekerjaan seseorang yang responnya adalah kumpulan perasaan dan kepercayaan yang mempengaruhi terhadap berbagai segi dari pekerjaan orang.

Teori keadilan (equity theory). Teori ini mengemukakan bahwa orang akan merasa puas atau tidak puas, tergantung pada ada atau tidaknya keadilan (equity) dalam suatu situasi, khususnya situasi kerja. Menurut teori ini komponen utama dalam teori keadilan adalah input, basil, keadilan dan ketidakadilan. Input adalah faktor bernilai bagi karyawan yang dianggap mendukung pekerjaannya, seperu pendidikan, pengalaman, kecakapan, jumlah tugas dan peralatan atau perlengkapan yang dipergunakan untuk melaksanakan pekerjaannya. Hasilnya adalah sesuatu yang dianggap bernilai oleh seorang karyawan yang diperoleh dari pekerjaannya, seperti: upah/gaji, keuntungan sampingan, simbol, status, penghargaan dan kesempatan untuk berhasil atau aktualisasi diri. Sedangkan orang selalu membandingkan dapat berupa seseorang di perusahaan yang sama, atau di tempat lain atau bisa pula dengan dirinya di masa lalu. Menurut teori ini, setiap karyawan akan membandingkan rasio input hasil dirinya dengan rasio input hasil orang lain. Bila perbandingan itu dianggap cukup adil, maka karyawan akan merasa puas. Bila perbandingan itu tidak seimbang tetapi menguntungkan bisa menimbulkan kepuasan, tetapi bisa pula tidak. Tetapi bila perbandingan itu tidak seimbang akan timbul ketidakpuasan.

Teori dua faktor (two factor theory). Menurut teori ini kepuasan kerja dan ketidakpuasan kerja itu merupakan hal yang berbeda. Kepuasan dan ketidakpuasan terhadap pekerjaan itu bukan suatu variabel yang kontinu. Teori ini merumuskan karakteristik pekerjaan menjadi dua kelompok yaitu satisfies atau motivator dan dissatisfies. Satisfies ialah faktor-faktor atau situasi yang dibutuhkan sebagai sumber kepuasan kerja yang terdiri dari: pekerjaan yang menarik, penuh tantangan, ada kesempatan untuk berprestasi, kesempatan memperoleh penghargaan dan promosi. Terpenuhinya faktor tersebut akan menimbulkan kepuasan, namun tidak terpenuhinya faktor ini tidak selalu mengakibatkan ketidakpuasan. Dissatisfies (hygiene actors) adalah faktor-faktor yang menjadi sumber ketidakpuasan, yang terdiri dari: gaji/upah, pengawasan, hubungan antarpribadi, kondisi kerja dan status. Faktor ini diperlukan untuk memenuhi dorongan biologis serta kebutuhan dasar karyawan. Jika tidak terpenuhi faktor ini, karyawan tidak akan puas. Namun, jika besarnya faktor ini memadai untuk memenuhi kebutuhan tersebut, karyawan tidak akan kecewa meskipun belum terpuaskan. 


\section{Faktor-faktor Kepuasan Kerja}

Menurut Danfar (dalam As'ad \& Husnan, 1987), kepuasan kerja merupakan sikap positif yang menyangkut penyesuaian karyawan terhadap faktor-faktor yang mempengaruhinya. Faktor-faktor yang mempengaruhi kepuasan kerja, meliputi: (1) faktor kepuasan finansial, yaitu terpenuhinya keinginan karyawan terhadap kebutuhan finansial yang diterimanya untuk memenuhi kebutuhan mereka sehari-jari sehingga kepuasan kerja bagi karyawan dapat terpenuhi. Hal ini meliputi: sistem dan besarnya gaji, jaminan sosial, macam-macam tunjangan, fasilitas yang diberikan serta promosi; (2) faktor kepuasan fisik, yaitu faktor yang berhubungan dengan kondisi fisik lingkungan kerja dan kondisi fisik karyawan. Hal ini meliputi; jenis pekerjaan, pengaturan waktu kerja dan istirahat, perlengkapan kerja, keadaan ruangan/suhu, penerangan, pertukaran udara, kondisi kesehatan karyawan dan umur; (3) faktor kepuasan sosial, yaitu faktor yang berhubungan dengan interaksi sosial baik antar sesama karyawan, dengan atasannya maupun karyawan yang berbeda jenis pekerjaannya. Hal ini meliputi; rekan kerja, pimpinan yang adil dan bijaksana, serta pengarahan dan perintah yang wajar; (4) faktor kepuasan psikologi, yaitu berhubungan dengan kejiwaan karyawan. Hal ini meliputi minat, ketentraman dalam bekerja, sikap terhadap kerja, bakat, dan keterampilan.

\section{METODE}

Desain penelitian ini adalah asosiatif dengan menggunakan karyawan sebagai unit analisis. Jenis data yang digunakan dalam penelitian ini adalah data kuantitatif dan kualitatif melalui sumber data primer dan sekunder. Teknik pengambilan data yang digunakan adalah melalui wawancara dengan pihak perusahaan, penyebaran kuesioner kepada karyawan sebagai responden, dan juga studi pustaka dari berbagai literature dan jurnal.

Teknik pengambilan sempel yang dipakai penulis dalam penelitian ini adalah Probability Sample yaitu teknik sampling yang memberikan peluang yang sama bagi setiap unsur (anggota populasi untuk dipilih menjadi anggota sampel). Metode yang digunakan adalah Simple Random Sampling. Simple Random Sampling adalah pengambilan sempel anggota populasi dilakukan secara acak tanpa memeperhatikan strata yang ada didalam populasi itu. Pengambilan sampel itu sendiri dilakukan pada karyawan di CV Surya Raya.

Metode analisis yang dipakai adalah regresi sederhana dan uji hipotesis. Regresi sederhana, analisis regresi digunakan untuk memprediksikan seberapa jauh perubahan nilai variabel dependen, bila nilai variabel independen dimanipulasi/ diubah-ubah atau dinaikturunkan (Sugiono, 2009). Kuatnya hubungan antar variabel dihasilkan dari analisis korelasi dapat diketahui berdasarkan besar kecilnya koefisien korelasi. Bila koefisien korelasi minus (-), maka pada umumnya koefisien regresi juga minus (-) dan sebaliknya. Jadi antara korelasi dan regresi terdapat hubungan yang bersifat fungsional sebagai alat untuk analisis. Manfaat dari hasil analisis regresi adalah untuk membuat keputusan apakah naik dan menurunnya variabel independen dapat dilakukan melalui peningkatan variabel independen atau tidak. Persamaan regresi linier sederhana:

$$
\mathrm{Y}=\mathrm{a}+\mathrm{bx}
$$

Di mana:

$\mathrm{Y}=$ Subjek dalam variabel dependen yang diprediksikan

$\mathrm{a}=$ Harga Y ketika X-0 ( harga konstan)

$\mathrm{b}=$ Angka arah atau koefisien regresi

$\mathrm{X}=$ Subjek variabel independen yang mempunyai nilai tertentu. 
Uji hipotesis menggunakan derajat tingkat kepercayaan sebesar 95\%, di mana tingkat presisi $\alpha$ $=5 \%(0,05)$. Dasar pengambilan keputusan berdasarkan Sig:

Jika Sig $\leq 0,05$ maka H0 ditolak, artinya tidak signifikan

Jika Sig $\geq 0,05$ maka H0 iterima, artinya signifikan

\section{HASIL DAN PEMBAHASAN}

\section{Pengaruh Budaya Organisasi terhadap Kepuasan Kerja}

Dari tabel model summary diketahui $\mathrm{R}$ square adalah 0,063 . Hal ini berarti kepuasan kerja dapat di pengaruhi oleh budaya organisasi sebesar 6,3\%. Sedangkan sisanya sebesar $93,7 \%$ di pengaruhi oleh faktor-faktor lain. Angka $\mathrm{R}$ menunjukan bahwa korelasi Budaya Organisasi $\left(\mathrm{X}_{1}\right)$ dengan Kepuasan Kerja (Y) adalah 0,251. Angka 0,251 menunjukan hubungan yang rendah. Kemudian, variabel $\mathrm{X}_{1}$ dan $\mathrm{Y}$, harus dilakukan pengujaian signifikan hubungan antara kedua variabel tersebut. Pengujian tersebut dilakukan dengan melihat pada tabel Anova, yaitu:

Hipotesis:

$\mathrm{H}_{\mathrm{o}}$ : budaya organisasi tidak berpengaruh signifikan terhadap kepuasan kerja

$\mathrm{H}_{1}$ : budaya organisasi berpengaruh signifikan terhadap kepuasan kerja

Dasar pengambilan keputusan (dengan tingkat kepercayaan 95\%):

Sig $\geq 0,05$ maka Ho di terima

Sig $<0,05$ maka Ho di tolak

Keputusan:

Sig $=0,040$ yang artinya $<0,05$ maka Ho di tolak dan H1 di terima, sehingga dapat disimpulkan bahwa budaya organisasi berpengaruh signifikan terhadap kepuasan kerja

Pada table Coefficient menggambarkan persamaan regresi :

$Y=2,884+0,226 X_{1}$

Di mana $\mathrm{Y}=$ Kepuasan Kerja dan $\mathrm{X}_{1}=$ Budaya Organisasi

Dari persamaan regresi diatas dapat dikatakan bahwa jika budaya organisasi makin baik, maka kepuasan kerja juga akan meningkat.

\section{Pengaruh kepemimpinan terhadap kepuasan kerja}

Dari tabel Model summary diketahui R square adalah 0,001. Hal ini berarti kepuasan kerja dapat di pengaruhi oleh kepemimpinan sebesar $0,1 \%$. Sedangkan sisanya sebesar $99,9 \%$ di pengaruhi oleh faktor - faktor lain. Angka $\mathrm{R}$ menunjukan bahwa korelasi kepemimpinan $\left(\mathrm{X}_{2}\right)$ dengan Kepuasan Kerja (Y) adalah 0,320. Angka 0,320 menunjukan hubungan yang rendah. Kemudian, variabel $\mathrm{X}_{2}$ dan $\mathrm{Y}$, harus dilakukan pengujaian signifikan hubungan antara kedua variabel tersebut. Pengujian tersebut dilakukan dengan melihat pada tabel Anova, yaitu:

Hipotesis:

$\mathrm{H}_{\mathrm{o}} \quad$ : kepemimpinan tidak berpengaruh signifikan terhadap kepuasan kerja

$\mathrm{H}_{1}$ : kepemimpinan berpengaruh signifikan terhadap kepuasan kerja 
Dasar pengambilan keputusan (dengan tingkat kepercayaan 95\%):

Sig $\geq 0,05$ maka Ho di terima

Sig $<0,05$ maka Ho di tolak

Keputusan:

Sig $=0,798$ yang artinya $>0,05$ maka Ho diterima dan H1 ditolak, sehingga dapat disimpulkan bahwa kepemimpinan tidak berpengaruh signifikan terhadap kepuasan kerja

Pada table Coefficient menggambarkan persamaan regresi:

$$
Y=3,460+0,041 X_{2}
$$

Di mana $\mathrm{Y}=$ Kepuasan Kerja dan $\mathrm{X}_{2}=$ kepemimpinan

Dari persamaan regresi diatas dapat dikatakan bahwa jika kepemimpinan makin baik, maka kepuasan kerja juga akan meningkat.

\section{Pengaruh motivasi kerjaterhadap kepuasan kerja}

Dari tabel Model summary diketahui $\mathrm{R}$ square adalah 0,248. Hal ini berarti kepuasan kerja dapat di pengaruhi oleh motivasi kerja sebesar $24,8 \%$. Sedangkan sisanya sebesar $75,2 \%$ di pengaruhi oleh faktor-faktor lain. Angka $\mathrm{R}$ menunjukan bahwa korelasi motivasi kerja $\left(\mathrm{X}_{3}\right)$ dengan Kepuasan Kerja (Y) adalah 0,498. Angka 0,498 menunjukan hubungan yang cukup tinggi. Kemudian, variabel $\mathrm{X}_{2}$ dan $\mathrm{Y}$, harus dilakukan pengujaian signifikan hubungan antara kedua variabel tersebut. Pengujian tersebut dilakukan dengan melihat pada tabel Anova, yaitu:

Hipotesis:

$\mathrm{H}_{\mathrm{o}} \quad$ : motivasi kerja tidak berpengaruh signifikan terhadap kepuasan kerja

$\mathrm{H}_{1}$ : motivasi kerja berpengaruh signifikan terhadap kepuasan kerja

Dasar pengambilan keputusan (dengan tingkat kepercayaan 95\%):

Sig $\geq 0,05$ maka Ho di terima

Sig $<0,05$ maka Ho di tolak

\section{Keputusan:}

Sig $=0,000$ yang artinya $<0,05$ maka Ho ditolak dan H1 diterima, sehingga dapat disimpulkan bahwa motivasi kerja berpengaruh signifikan terhadap kepuasan kerja

Pada table Coefficient menggambarkan persamaan regresi:

$$
Y=2,425+0,360 \times 3_{2}
$$

Di mana $\mathrm{Y}=$ Kepuasan Kerja dan $\mathrm{X}_{2}=$ motivasi kerja

Dari persamaan regresi diatas dapat dikatakan bahwa jika motivasi kerja makin tinggi, maka kepuasan kerja juga akan meningkat.

\section{Analisis}

Dengan menggunakan regresi linear sederhana diperoleh bahwa variabel $\mathrm{X}_{2}$ ternyata tidak berpengaruh signifikan sementara variabel bebas lainnya $\left(\mathrm{X}_{1}\right.$ dan $\left.\mathrm{X}_{2}\right)$ berpengaruh signifikan. Angka Budaya organisasi yang rendah bisa diperoleh karena didalam CV Surya Raya didapati bukan sebagai organisasi tetapi kekeluargaan sehingga para karyawan yang sebagaian besar adalah driver yang merasakan bekerja di CV Surya Raya dengan sistem kekeluargaan tetapi dengan dipadukan dengan sistem kerja yang profesional oleh karena itu hasil analisis yang di dapat tergolong rendah. 
Sedangkan untuk variabel kepemimpinan yang diperoleh dari analisis yang dilakukan didapati angka yang paling kecil, itu dikarenakan kepemimpinan didalam CV Surya Raya tidak berpengaruh terhadap kepuasan kerja karyawannya, bisa disebabkan pemimpin dari perusahaan tersebut belum menerapkan kepemimpinan dengan benar seperti pembagian kerja yang dinilai kurang adil, atau cara berkomunikasi terhadap karyawan kurang diterima oleh seluruh karyawan yang kebanyakan adalah driver.

Motivasi Kerja menunjukan angka yang tergolong tinggi dengan nilai tertinggi dari pada variabel bebas yang lainnya, sesuai dengan hasil dari analisis yang didapati. Karyawan dari CV Surya Raya sangat termotivasi dan kepuasan bekerja mereka juga tinggi hal ini dikarenakan perusahaan memberikan upah kerja dan tunjangan yang layak dan para karyawan yang lain menjalin hubungan yang baik sehingga menimbulkan suasana kekeluargaan di dalam perusahaan. Dan sebagai varibel terkait dalam penelitian ini, kepuasan karyawan di CV Surya Raya juga didapati cukup baik. Hal ini di peroleh karena mereka memiliki motivasi kerja yang tinggi terhadap pekerjaan mereka, dan juga memiliki etika kerja yang baik. Mereka pun mengerjakan pekerjaan mereka sesuai denga prosedur yang ada. Pihak dari CV Surya Raya pun berperan besar dalam meningkatkan kepuasan dalam bekerja dan secara langsung akan meningkatkan kinerja mereka, dengan memberikan pengarahan untuk bekerja sesuai dengan ketentuan pekerjaan yang berlaku, memberikan suasana kerja yang layak.

\section{SIMPULAN}

Dalam hubungan variabel budaya organisasi terhadap kepuasan kerja didapati korelasi yang rendah dengan pengaruh yang signifikan sebesar 6,3\% dengan persamaan regresi $Y=2,884+0,226 \mathrm{X}_{1}$. Dalam hubungan variabel kepemimpinan terhadap kepuasan kerja didapati korelasi yang rendah, variabel ini tidak berpengaruh yang signifikan sebesar $0,1 \%$ dengan persamaan regresi $\mathrm{Y}=$ $3,460+0,041 \mathrm{X}_{2}$. Dalam hubungan variabel motivasi kerja terhadap kepuasan kerja didapati korelasi yang rendah dengan pengaruh yang signifikan sebesar $24,8 \%$ dengan persamaan regresi $\mathrm{Y}=$ $2,425+0,360 \mathrm{X}_{3}$

\section{Saran}

Perlunya meningkatkan budaya organisasi didalam perusahaan CV Surya raya. Dari hasil penelitian kami terhadap budaya organisasi, didapati beberapa yang harus diperbaiki dan ditingkatkan perihal penerapan budaya organisasinya, seperti; perusahaan harusnya lebih mendorong kepada karyawan untuk fokus pada hasil pekerjaan, perusahaan jangan membatasi kreasi dari para karyawannya, dan perusahaan lebih mendorong para karyawannya untuk lebih mempunyai daya saing yang kompetitif. Untuk variabel motivasi kerja, ada beberapa usulan perbaikan untuk CV Surya Raya, yaitu memenuhi kebutuhan fisik karyawan seperti; memberikan tunjangan kesehatan dan asuransi kepada karyawannya. 


\section{DAFTAR PUSTAKA}

As'ad, M. H., \& Husnan, S. (1987). Faktor-faktor yang mempengaruhi kepuasan kerja. Diakses pada 10 April 2009, dari: http://dansite.wordpress.com/2009/04/10/faktor-faktoryangmempengaruhi-kepuasan-kerja/

Brahmasari, I. A., \& Suprayetno, A. (2008). Pengaruh motivasi kerja, kepemimpinan dan budaya organisasi terhadap kepuasan kerja karyawan serta dampaknya pada kinerja perusahaan: Studi kasus pada PT Pei Hai International Wiratama Indonesia. Jurnal Manajemen dan Kewirausahaan, 10(2), 124-135.

Colquitt, Lepine, \& Wesson. (2009). Organizational behavior. McGraw-Hill.

Cushway, B., \& Lodge, D. (2000). Organizational behaviour and design. Crest Pub House.

George, \& Jones. (2005). Understanding and managing organizational behavior. Pearson, Prentice Hall.

Kreitner, \& Kinicki. (2008). Organizational behavior. Thomson South-Western.

Madura, J. (2001). Pengantar bisnis. Jakarta: Salemba Empat.

Munandar, A. S. (2001). Psikologi industri dan organisasi. Jakarta: Universitas Indonesia.

Rivai, V., \& Jauvani, E. (2009). Manajemen sumber daya manusia untuk perusahaan. Rajawali Pers.

Robbins, S. P., \& Coulter, M. (2004). Management. Prentice Hall.

Samsudin, S. (2006). Manajemen sumber daya manusia. Bandung: Pustaka Setia.

Wood, Wallace, Zeffane, Schermerhorn, Hunt, \& Osborn. (2001). Historical foundations of organisational behavior. John Wiley \& Sons. 